\title{
Article \\ Biochemical Characterization, Antifungal Activity, and Relative Gene Expression of Two Mentha Essential Oils Controlling Fusarium oxysporum, the Causal Agent of Lycopersicon esculentum Root Rot
}

\author{
Seham A. Soliman ${ }^{1}$, Elsayed E. Hafez ${ }^{1}$ (D), Abdu M. G. Al-Kolaibe ${ }^{2}$, El-Sayed S. Abdel Razik ${ }^{1}$, \\ Sawsan Abd-Ellatif ${ }^{3}$, Amira A. Ibrahim ${ }^{1}$ (D) , Sanaa S. A. Kabeil ${ }^{4}$ and Hazem S. Elshafie ${ }^{5, *(D)}$
}

check for updates

Citation: Soliman, S.A.; Hafez, E.E.; Al-Kolaibe, A.M.G.; Abdel Razik,

E.-S.S.; Abd-Ellatif, S.; Ibrahim, A.A.;

Kabeil, S.S.A.; Elshafie, H.S

Biochemical Characterization, Antifungal Activity, and Relative Gene Expression of Two Mentha Essential Oils Controlling Fusarium oxysporum, the Causal Agent of Lycopersicon esculentum Root Rot. Plants 2022, 11, 189. https://doi.org/ $10.3390 /$ plants 11020189

Academic Editor: Franklin Gregory

Received: 14 December 2021

Accepted: 5 January 2022

Published: 11 January 2022

Publisher's Note: MDPI stays neutral with regard to jurisdictional claims in published maps and institutional affiliations.

Copyright: (C) 2022 by the authors. Licensee MDPI, Basel, Switzerland. This article is an open access article distributed under the terms and conditions of the Creative Commons Attribution (CC BY) license (https:// creativecommons.org/licenses/by/ $4.0 /)$.
1 Plant Protection and Biomolecular Diagnosis Department, Arid Lands Cultivation Research Institute, City of Scientific Research and Technology Applications, Borg EL-Arab, Alexandria 21934, Egypt; sehamsoliman50@yahoo.com (S.A.S.); elsayed_hafez@yahoo.com (E.E.H.); eshabaan@srtacity.sci.eg (E.-S.S.A.R.); amiranasreldeen@yahoo.com (A.A.I.)

2 Microbiology Department, Faculty of Science, Taiz University, Taiz 6803, Yemen; abdu_71@yahoo.com

3 Bioprocess Development Department, Genetic Engineering and Biotechnology Research Institute, City of Scientific Research and Technology Applications, Borg EL-Arab, Alexandria 21934, Egypt; sabdellatif@srtacity.sci.eg

4 Protein Research Department, Genetic Engineering and Biotechnology Research Institute, City of Scientific Research and Technology Applications, Borg EL-Arab, Alexandria 21934, Egypt; sanaa.protein@gmail.com

5 School of Agricultural, Forestry, Food and Environmental Sciences, University of Basilicata, Viale dell'Ateneo Lucano 10, 85100 Potenza, Italy

* Correspondence: hs.elshafie@gmail.com; Tel.: +39-0971-205522; Fax: +39-0971-205503

\begin{abstract}
Tomato (Lycopersicon esculentum Mill.) is important food in daily human diets. Root rot disease by Fusarium oxysporum caused huge losses in tomato quality and yield annually. The extensive use of synthetic and chemical fungicides has environmental risks and health problems. Recent studies have pointed out the use of medicinal plant essential oils (EOs) and extracts for controlling fungal diseases. In the current research, Mentha spicata and Mentha longifolia EOs were used in different concentrations to control F. oxysporum. Many active compounds are present in these two EOs such as: thymol, adapic acid, menthol and menthyl acetate. These compounds possess antifungal effect through malformation and degradation of the fungal cell wall. The relative expression levels of distinctly upregulated defense-related WRKY genes (WRKY1, WRKY4, WRKY33 and WRKY53) in seedling root were evaluated as a plant-specific transcription factor (TF) group in different response pathways of abiotic stress. Results showed significant expression levels of WRKY, WRKY53, WRKY33, WRKY1 and WRKY4 genes. An upregulation was observed in defense-related genes such as chitinase and defensin in roots by application EOs under pathogen condition. In conclusion, M. spicata and M. longifolia EOs can be used effectively to control this plant pathogen as sustainable and eco-friendly botanical fungicides.
\end{abstract}

Keywords: WRKY transcription factor; essential oils; Fusarium root rot; Mentha spicata; Mentha longifolia GC-MS; antioxidant enzymes; antifungal activity

\section{Introduction}

The tomato plant (Lycopersicon esculentum Mill.) is considered one of the third most important vegetable plants worldwide. Moreover, it is one of the most widespread vegetable crops grown across the globe. The tomato plant is highly sensitive to various biotic and abiotic stresses, which results in high economic losses [1,2]. The biotic stress which affects tomato plant growth and production is Fusarium oxysporum f. sp. lycopersici (Fol) [3]. Fusarium oxysporum is a soil-borne pathogen that targets the plant by attacking the tomato 
roots, resulting in wilt disease [4]. Wilt disease frequency in tomato crops is very high in some countries where it reaches up to $25 \pm 5 \%[5,6]$.

Additionally, in the presence of suitable conditions for the fungus, especially in developing countries, economic losses may increase up to $80 \%$ [7]. Consequently, the fungus gains its capability in tomato infection through secretion of mycotoxins [8], which have hazardous effects on animal and human health [9]. Mint essential oil (EO) has been reported to have a strong antimicrobial activity against several pathogenic microorganisms $[10,11]$. Many researchers have studied the biological activity of different EOs from Mentha against different pathogenic fungi, especially Fusarium species [11-15]. In particular, the two studied Mentha EOs have illustrated a strong antifungal activity against potato pathogens in addition to different soil-borne diseases in tomatoes [16-18].

The most active chemical compounds in EOs of Mentha species are piperitone oxide, pulegone, and 3-cyclopenten-1-one, 2-hydroxy-3-(3-methyl-2-butenyl) [19,20]. These compounds play an important role in defense against pests, pathogens, and fungi [21-23]. Sharma et al. [24] studied the effect of mint, clove, lemongrass, and eucalyptus EOs on wilt-causing fungus F. oxysporum. Plants' EOs have a vital role in enhancing plant defense systems by increasing the production of phytochemicals as phenolic compounds and peroxidases enzymes which lead to strengthening of the cell wall and increasing lignification against phytopathogens [25].

When any pathogen infects plants, it is well known that they induce a plant's defense system which works to resist both the pathogen attack and development of disease [26]. The plant defense system works once the plant is exposed to any stress; plant transcription factors belonging to multiple families play a critical role in stress mitigation or other adjustment mechanisms by modulating the gene expression patterns [27]. There is a large gene family, "WRKY", which is considered the transcriptional factors distributed in all plant parts [28]. In addition, the WRKY genes were previously discovered in non-photosynthetic eukaryotes [29], and consequently have been identified and characterized in different plant species [30,31].

The main role of WRKY genes is defense; these genes work in the plant acquired resistance by using different pathways, including different enzymes [32]. Researchers have reported that they play a role in the defense mechanism of the Arabidopsis plant infected with necrotrophic fungal pathogens Botrytis cinerea and Alternaria brassicicola [33]. Several studies revealed that WRKY genes might bind with the promoter of phytoalexin deficient 3 and 1-aminocyclopropane-1-carboxylic acid synthase 2 when the plant is attacked by Botrytis cinerea [34].

The aims of the present study are (i) investigating the potential antifungal activities of different concentrations of M. spicata and M. longifolia EOs against Fusarium root rot disease caused by F. oxysporum in tomato plant; (ii) demonstrating the possible alterations in seedling germination, total phenols, and the activity of several antioxidant enzymes; and (iii) discovering the mode of action between the fungus and plant through analyzing the expression levels of defense-related genes as chitinase (PR3) and defensin (PR12) and WRKY transcriptional factors (TFs) (such as WRKY1, WRKY4, WRKY33, and WRKY53) by investigating the upregulation or downregulation profile of studied defense and WRKY genes against Fusarium attack.

\section{Results}

\subsection{Screening of Antifungal Activity of Studied EOs}

Antifungal activity of M. spicata and M. longifolia EOs at various concentrations $(0.25 \%$, $0.5 \%, 0.75 \%, 1.0 \%$, and $1.25 \%$ ) was investigated against $F$. oxysporum. The average reductions in F. oxysporum radial growth in response to M. spicata and M. longifolia EOs colloid treatment are shown in the graph (Figure 1).

All tested concentrations exhibited varied inhibitory activity compared with positive control fungicide (nystatin $0.005 \%$ ) and the untreated experimental control. Inhibition of mycelium growth increased with time and complete growth reduction was achieved 
after 7 days of incubation at $28 \pm 2{ }^{\circ} \mathrm{C}$ in the case of $M$. longifolia EOs at $1.0 \%$ and $1.25 \%$. Whereas, the highest significant growth inhibition $\left(92.55^{* *} \pm 0.08 \%\right.$ and $\left.90.63^{* *} \pm 0.04\right)$ was achieved in the case of M. spicata EO (1.25\%) and nystatin $(0.005 \%)$, respectively, compared with control. The lowest insignificant growth inhibition, $14.33 \mathrm{~ns} \%$, was obtained with M. spicata $\mathrm{EO}$ at $0.25 \%$.

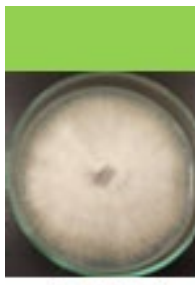

$0.25 \%$

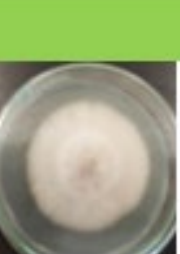

$0.25 \%$

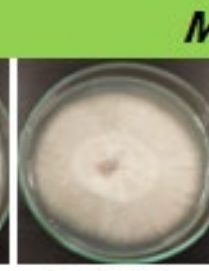

$0.50 \%$

M. spicata

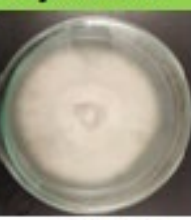

$0.75 \%$
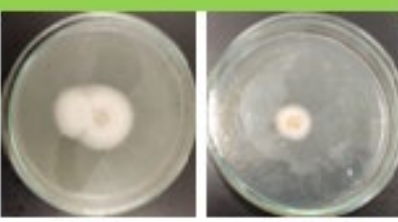

$1.0 \%$

$1.25 \%$

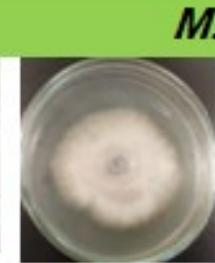

M. Iongifolia

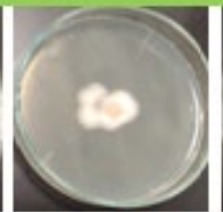

$0.50 \%$

$0.75 \%$
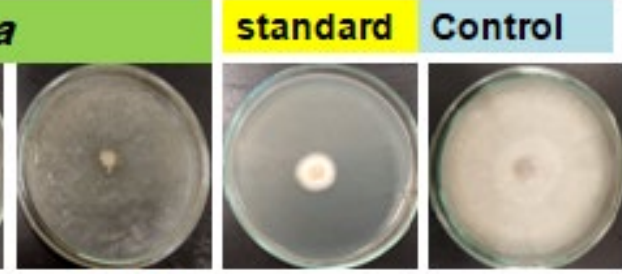

$1.0 \%$

Figure 1. Effects of the two studied EOs at different concentrations on mycelial growth reduction percentages of F. oxysporum after 7 days of incubation at $28 \pm 2{ }^{\circ} \mathrm{C}$.

\subsection{Chemical Composition of Mentha EOs}

Selected GC-MS analysis chromatograms of the two studied EOs are shown in Figures 2 and 3. The component relative concentrations (calculated as GC peak area percentages and retention index) are shown in Tables 1 and 2. GC-MS results identified that the principal bioactive components belonged to different chemical groups. The major constituents in M. spicata EO included thymol (28.19\%), adipic acid $(25.82 \%)$, piperitone $(24.76 \%)$, and menthol $(24.18 \%)$, whereas, the major constituents in $M$. longifolia EO included menthol (51.4\%), menthyl acetate (20.5\%), and d-limonene (11.15\%).

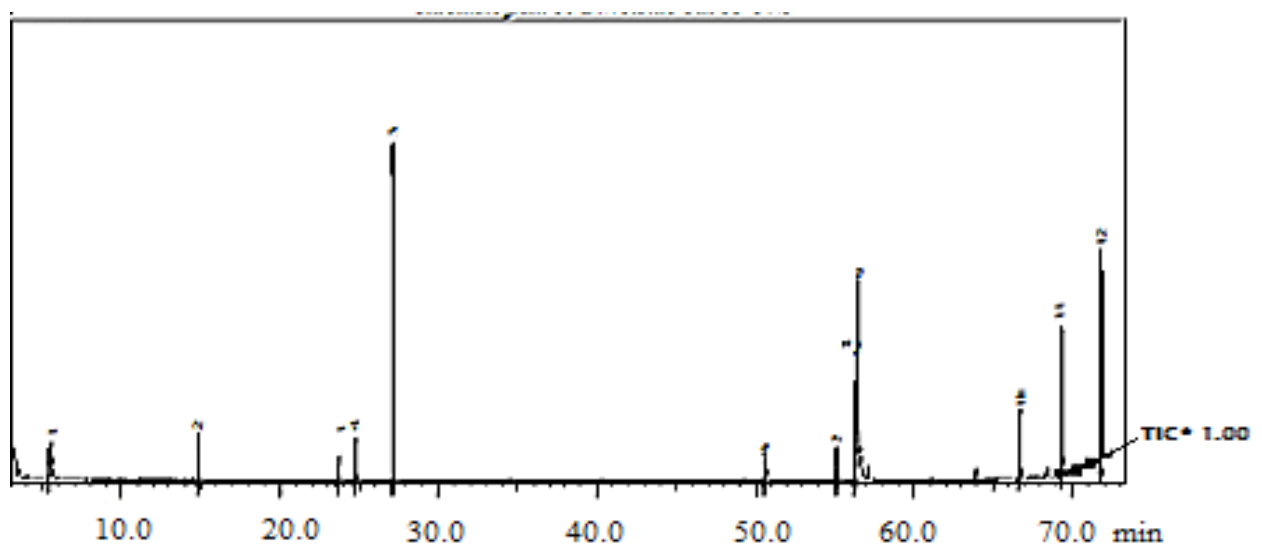

Figure 2. GC-MS chromatogram of M. spicata EO. Where $\left(^{*}\right)$ is the Total Ion Current. 


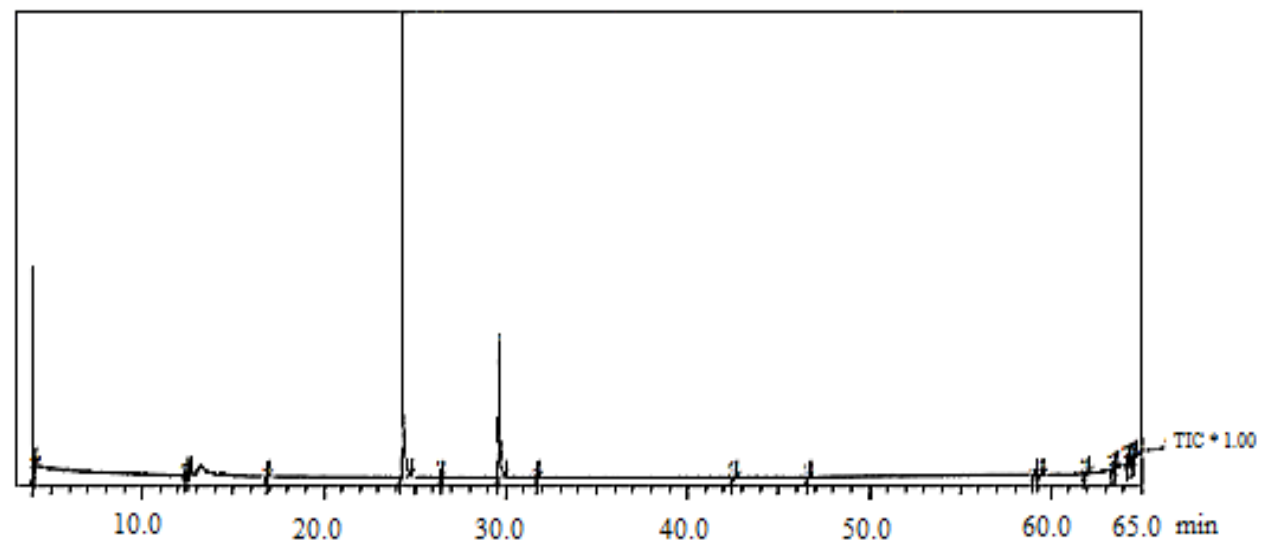

Figure 3. GC-MS chromatogram of M. longifolia EO. Where $\left(^{*}\right)$ is the Total Ion Current.

Table 1. The relative percentage of the area of peak of $M$. spicata $\mathrm{EO}$ constituents.

\begin{tabular}{|c|c|c|c|c|c|}
\hline Quantitative ID & Component Identified & $\begin{array}{c}\text { Retention Time } \\
\text { (min) }\end{array}$ & $\begin{array}{l}\text { Retention Index } \\
\text { (RI) }\end{array}$ & Area $(\%)$ & Identification \\
\hline 1 & Piperitone & 5.20 & 1245 & 12.34 & RI, MS \\
\hline 2 & IR-alpha-pinene & 7.82 & 933 & 0.76 & RI, MS \\
\hline 3 & D-limonene & 11.83 & 1031 & 0.77 & RI, MS \\
\hline 4 & Cis-P-menthan & 17.63 & 984 & 0.99 & RI, MS \\
\hline 5 & Menthone & 18.13 & 1150 & 0.67 & RI, MS \\
\hline 6 & P-menthan-3-ol alcohol & 18.55 & 1164 & 2.27 & RI, MS \\
\hline 7 & Alpha-terpin & 19.49 & 1187 & 6.11 & RI, MS \\
\hline 8 & Gamma-terpineol & 19.73 & 1185 & 0.82 & RI, MS \\
\hline 9 & $\beta$-caryophyllene & 27.19 & 1325 & 18.7 & RI, MS \\
\hline 10 & Butanedioic acid & 32.28 & 1580 & 6.26 & RI, MS \\
\hline 11 & Ethyl 4-heptyl ester & 36.54 & 1378 & 8.83 & RI, MS \\
\hline 12 & Adipic acid & 56.70 & 1507 & 13.24 & RI, MS \\
\hline 13 & Menthol & 66.70 & 1182 & 12.08 & RI, MS \\
\hline 14 & Thymol & 72.10 & 1290 & 14.62 & RI, MS \\
\hline 15 & Others & - & - & 1.54 & RI, MS \\
\hline
\end{tabular}

MS: Mass spectrometry (GC-MS).

Table 2. The relative percentage of the area of peak M. longifolia EO constituents.

\begin{tabular}{|c|c|c|c|c|c|}
\hline $\begin{array}{l}\text { Quantitative } \\
\text { ID }\end{array}$ & Component Identified & $\begin{array}{l}\text { Retention Time } \\
\text { (min) }\end{array}$ & $\begin{array}{l}\text { Retention Index } \\
\text { (RI) }\end{array}$ & Area $(\%)$ & Identification \\
\hline 1 & Alpha piene & 4.05 & 933 & 6.87 & RI, MS \\
\hline 2 & $\beta$-pinene & 12.21 & 964 & 0.54 & RI, MS \\
\hline 3 & D-limonene & 12.43 & 1031 & 10.33 & RI, MS \\
\hline 4 & Borneol & 12.72 & 1165 & 0.38 & RI, MS \\
\hline 5 & $\beta$-terpinyl acetate & 16.89 & 1267 & 0.47 & RI, MS \\
\hline 6 & Menthol & 24.32 & 1182 & 44.17 & RI, MS \\
\hline 7 & Menthone & 26.48 & 1150 & 0.55 & RI, MS \\
\hline 8 & Menthyl acetate & 29.63 & 1294 & 18.36 & RI, MS \\
\hline 9 & Linalool & 31.74 & 1083 & 0.43 & RI, MS \\
\hline 10 & Eugenol & 43.6 & 1209 & 0.64 & RI, MS \\
\hline 11 & Carvone & 46.89 & 1242 & 0.33 & RI, MS \\
\hline 12 & Thymol & 5.08 & 1290 & 11.23 & RI, MS \\
\hline 13 & Cavacrol & 59.55 & 1298 & 0.36 & RI, MS \\
\hline 14 & Cis-jasmone & 63.41 & 1394 & 0.56 & RI, MS \\
\hline 15 & Cinerolone & 63.52 & 1641 & 0.53 & RI, MS \\
\hline 16 & Caryophyllene & 64.32 & 1418 & 0.74 & RI, MS \\
\hline 17 & $\beta$-farnesene & 64.38 & 1452 & 0.35 & RI, MS \\
\hline 18 & $\beta$-cubebene & 64.57 & 1389 & 0.36 & RI, MS \\
\hline 19 & Alpha-cadinol & 64.78 & 1627 & 0.82 & RI, MS \\
\hline 20 & Others & - & - & 1.98 & RI, MS \\
\hline
\end{tabular}




\subsection{Effects of EOs on Tomato Growth Parameters}

Tomato seedlings, treated with the highest concentrations (1.0\% and $1.25 \%)$ of $M$. spicata and $M$. longifolia, respectively showed in vitro complete and maximum reduction in mycelial growth in F. oxysporum colonies and disease incidence of Fusarium root rot compared with untreated control (Figure 4). The magnitude of root rot symptoms and disease severity $(86.39 \pm 0.025)$ was observed in Fusarium inoculated experiments, whereas a significant reduction in root rot disease severity by $5.6 \pm 0.01 \%$ and $3.5 \pm .02 \%$ was shown in treated plants with $1.25 \%$ M. spicata and $1.0 \%$ M. longifolia EOs treatments.

In addition, the application of $1.25 \%$ M. spicata and $1.0 \%$ M. longifolia EOs exhibited a significant increase in the following growth parameters: plant height, shoot and root fresh, and dry weights, compared with treated-infected, infected, and negative control EOs (Table 3). A remarkable maximum plant height $(32.42 \pm 0.02 \mathrm{~cm}$ ) was observed in the case of $1.0 \%$ M. longifolia-treated plants followed by $(28.9 \pm 0.01 \mathrm{~cm})$ with $1.25 \% \mathrm{M}$. spicata treatment compared with control $(24.32 \pm 0.02)$. In contrast, the lowest plant height $(16.54 \pm 0.02)$ was observed in the case of pathogen-inoculated plants. The treatment with $1.0 \% M$. spicata and $M$. longifolia resulted in a significant increase in all other measured germination features such as radicle and root lengths, and fresh and dry weights of radicle and root compared with control (Figure 4), while germination features were greatly decreased due to fungal infestation, where a clear root rot severity was observed. The total chlorophyll content and electrical leakage results are shown in Figures 5 and 6 where the maximum chlorophyll content $(74.16 \pm 0.01$ and $62.33 \pm 0.02)$ were measured in $1.0 \%$ M. longifolia and $1.25 \%$ M. spicata, respectively, compared with Fusarium inoculated plants (42.06 \pm 0.02$)$. Whereas, the maximum electrical leakage (EL \%) (127.18 \pm 0.01$)$ was recorded in pathogentreated plants with $1.25 \%$ M. spicata compared with $(6.97 \pm 0.01)$ in case of control.
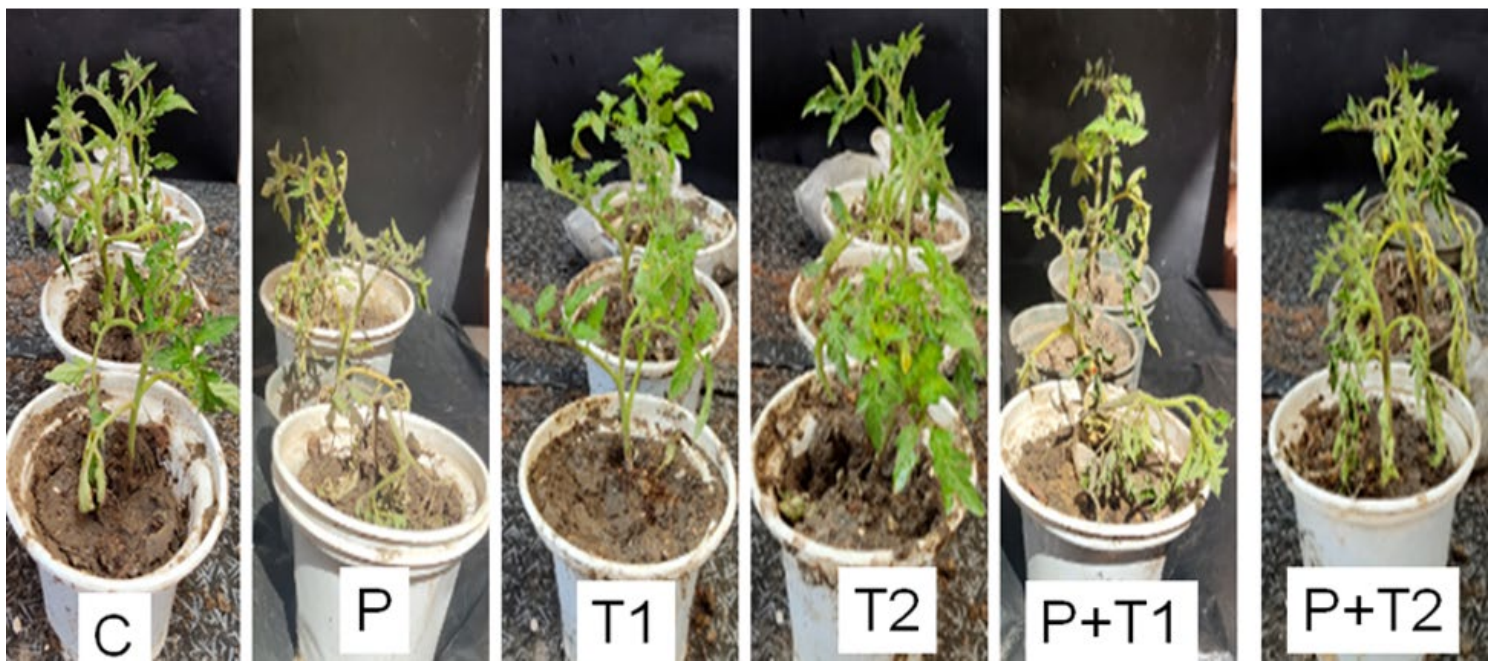

Figure 4. Effects of highest concentrations of M. spicata and M. longifolia EOs formulations on L. esculentum seedling growth potential under Fusarium root rot disease infection. $\mathrm{C}=$ control, $\mathrm{P}=$ pathogen, $\mathrm{T} 1=1.25 \% \mathrm{M}$. spicata, $\mathrm{T} 2=1 \% \mathrm{M}$. longifolia, $\mathrm{P}+\mathrm{T} 1=$ pathogen $+1.25 \% \mathrm{M}$. spicata, and $\mathrm{P}+\mathrm{T} 2=$ pathogen $+1 \%$ M. longifolia.

\subsection{Protein, Total Phenols, Flavonoids, Malondialdehyde Contents, and Antioxidant Enzymes}

Data presented in Figures 7 and 8 represent the effects of M. spicata and M. longifolia application on L. esculentum seedling on lipid peroxidation level, protein content (PC), total phenols content (TPC), total flavonoids content (TFC), and different antioxidant enzymes of L. esculentum seedling in all treatments of 35 DAS and $1.25 \%$ M. spicata and $1.0 \%$ M. longifolia application under Fusarium root rot infection. Overall, the pathogeninfected plants showed significant increase in MDA level, TPC, and TFC contents compared with the untreated control, whereas $M$. spicata and M. longifolia applications showed a slight 
increase in MDA, TPC, and TFC. In addition, PC of pathogen-infected plants treated with $1.25 \%$ M. spicata and $1.0 \%$ M. longifolia had the highest content at $19.09 \mu \mathrm{mol} / \mathrm{g}$ and $18.54 \mu \mathrm{mol} / \mathrm{g}$ of FW, respectively, compared with control and pathogen-infected plants.

Assessed results of antioxidant enzymes in Figure 8 show the effect of Fusarium infection and $1.25 \%$ M. spicata and $1.0 \%$ M. longifolia applications for two weeks of seedling transplantation on SOD, CAT, and APOX enzymes activities in L. esculentum plant leaves. Our results reveal a significant increase in SOD, CAT, and APOX enzymes activities in all treatments and Fusarium-infected experiments compared with untreated control.

\section{5. qRT-PCR of the Plant Defence System}

qRT-PCR was carried out with mRNA to assess the expression levels of different WRKY transcription factors WRKY1, WRKY4, WRKY33, and WRKY53 (Figures S1-S4) which play an important role in biotic and abiotic tolerance. In addition, qRT-PCR represented the relative expression levels of defense-related proteins such as chitinase (PR3) and defensin (PR12) genes (Figures S5 and S6) in tomato plant roots after two weeks from Fusarium inoculation and EOs application, respectively.

Table 3. Effects of M. spicata and M. longifolia EOs on L. esculentum seedling growth under Fusarium root rot disease infection.

\begin{tabular}{ccccccc}
\hline & EOs Treatment & PH $(\mathbf{c m})$ & SFW $(\mathbf{g})$ & SDW $(\mathbf{g})$ & RFW $(\mathbf{g})$ & RDW \\
\hline \multirow{5}{*}{ Control } & Control Plants & $24.32 \pm 0.02 \mathrm{c}$ & $15.44 \pm 0.02 \mathrm{c}$ & $1.98 \pm 0.01 \mathrm{c}$ & $1.52 \pm 0.01 \mathrm{c}$ & $0.16 \pm 0.01 \mathrm{c}$ \\
& $1.25 \%$ M. spicata & $28.9 \pm 0.01 \mathrm{~b}$ & $15.96 \pm 0.02 \mathrm{~b}$ & $2.09 \pm 0.01 \mathrm{~b}$ & $1.64 \pm 0.01 \mathrm{~b}$ & $0.18 \pm 0.01 \mathrm{~b}$ \\
& $1 \%$ M. longifolia & $32.42 \pm 0.02 \mathrm{a}$ & $16.33 \pm 0.01 \mathrm{a}$ & $2.34 \pm 0.01 \mathrm{a}$ & $1.87 \pm 0.01 \mathrm{a}$ & $0.24 \pm 0.01 \mathrm{a}$ \\
& Infected Plants & $16.54 \pm 0.02 \mathrm{f}$ & $9.52 \pm 0.03 \mathrm{f}$ & $0.97 \pm 0.01 \mathrm{f}$ & $1.21 \pm 0.02 \mathrm{f}$ & $0.1 \pm 0.01 \mathrm{f}$ \\
& $1.25 \%$ M. spicata & $18.76 \pm 0.01 \mathrm{e}$ & $12.97 \pm 0.01 \mathrm{e}$ & $1.67 \pm 0.01 \mathrm{e}$ & $1.34 \pm 0.15 \mathrm{e}$ & $0.12 \pm 0.01 \mathrm{e}$ \\
& $1 \%$ M. longifolia & $19.86 \pm 0.02 \mathrm{~d}$ & $13.64 \pm 0.01 \mathrm{~d}$ & $1.85 \pm 0.01 \mathrm{~d}$ & $1.41 \pm 0.02 \mathrm{~d}$ & $0.14 \pm 0.01 \mathrm{~d}$ \\
\hline
\end{tabular}

$\mathrm{PH}=$ plant height, $\mathrm{SFW}=$ shoot fresh weight, $\mathrm{SDW}=$ shoot dry weight, $\mathrm{RFW}=$ root fresh weight, $\mathrm{RDW}$ = root dry weight, and EOs = essential oils. Different letters indicate significant differences between different treatments at $p \leq 0.05$. Data are expressed as the mean of three replicates \pm SDs.

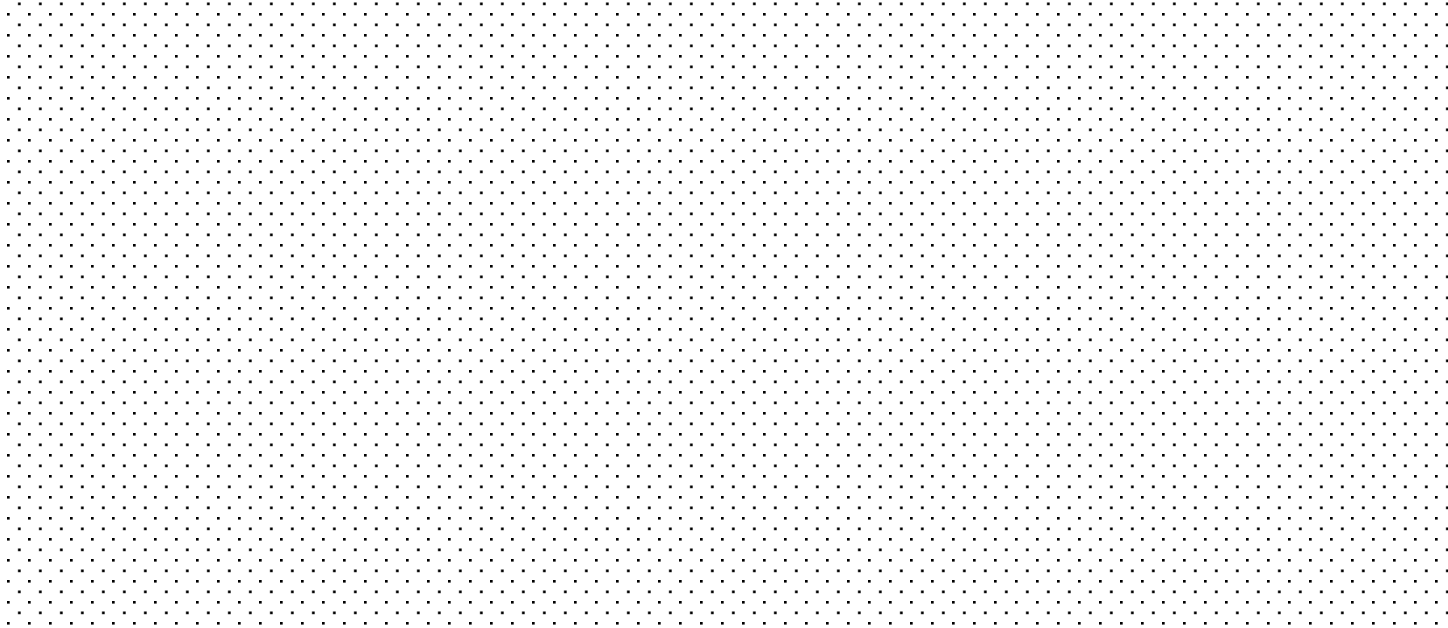

Figure 5. Effects of highest concentrations of M. spicata and M. longifolia EOs on total chlorophyll content (Chll) in L. esculentum seedling under Fusarium root rot disease infection. Bars with different letters indicate significant differences between treatments at $p \leq 0.05$. Data are expressed as the mean of three replicates \pm SDs. 


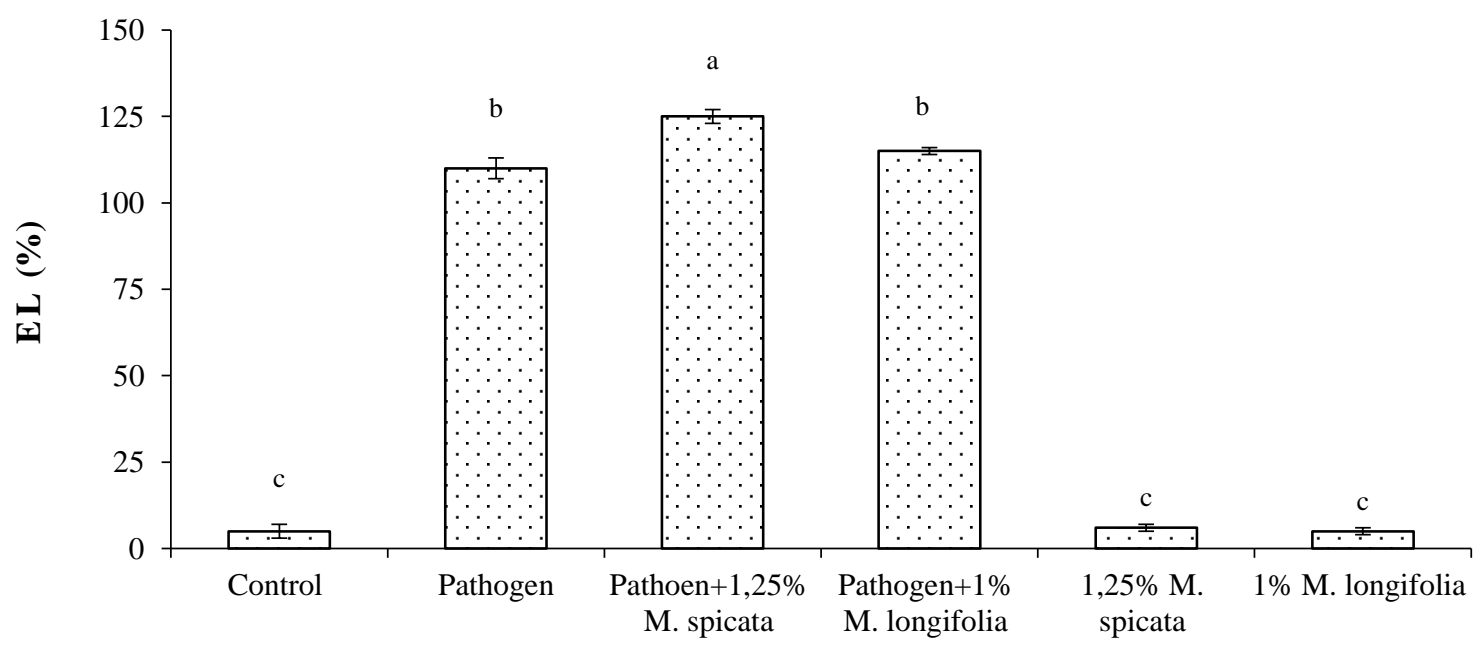

Figure 6. Effects of highest concentrations of M. spicata and M. longifolia EOs on electrical leakage percentage (EL\%) in L. esculentum seedling leaves under Fusarium root rot disease conditions. Bars with different letters indicate significant differences between treatments at $p \leq 0.05$. Data are expressed as the mean of three replicates \pm SDs.

In our study, the highest expression mRNA level (57.24 \pm 0.01$)$ was recorded for chitinase gene in L. esculentum plant roots at $1.0 \% \mathrm{M}$. longifolia under Fusarium infection, followed with $(57.16 \pm 0.02,56.4 \pm 0.02)$ of pathogen and M. spicata application treatments, respectively, compared with $(1.0 \pm 0.0)$ in untreated control treatments. Overall, the WRKY TFs genes (WRKY1, WRKY4, WRKY33, and WRKY53) in tomato seedling roots showed positive expression levels (upregulation) under $M$. spicata and $M$. longifolia treatments and positive control, compared with the untreated control. The highest expression mRNA levels of WRKY transcriptional factors WRKY53 gene (39.233 \pm 0.03$)$ represented in tomato roots at $1.0 \% \mathrm{M}$. longifolia treatment under Fusarium infection condition, followed with $(38.12 \pm 0.02)$ in pathogen treatment. Figure 9 shows a hierarchical clustering heat map and the correlation among different treatments and their gene expression. The red color demonstrates the highest correlation, and the blue color demonstrates the lowest correlation.

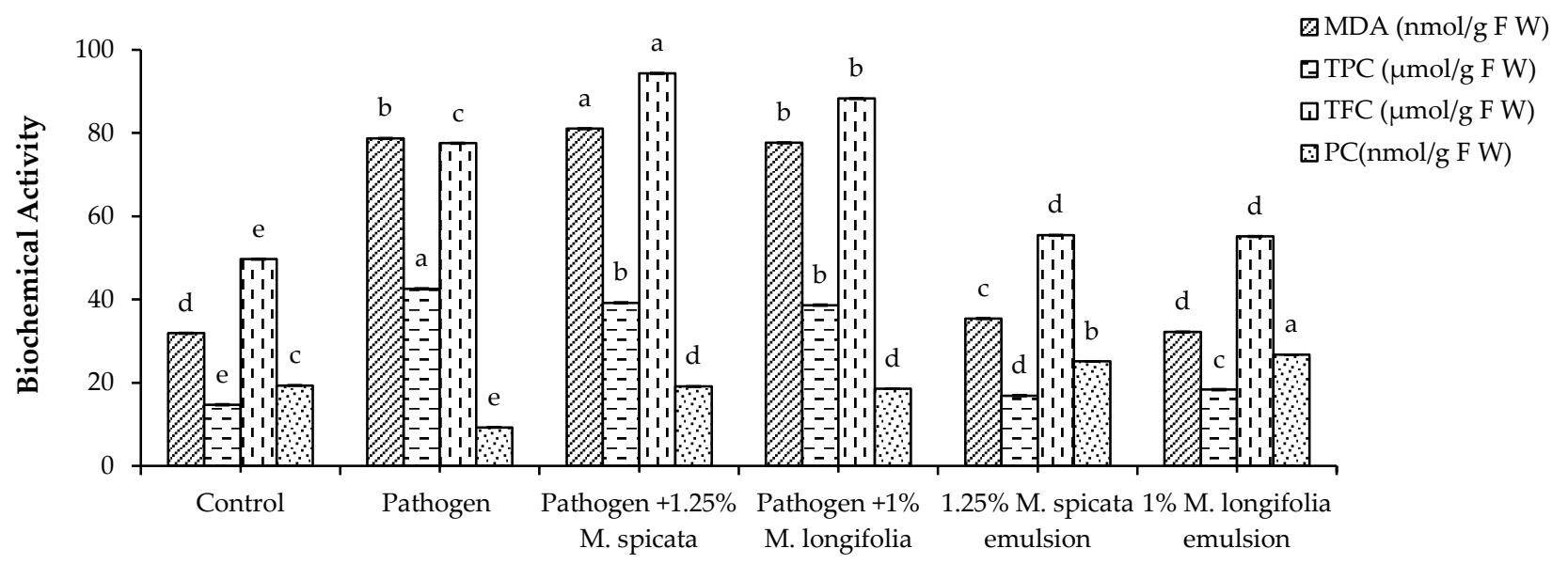

Figure 7. Effects of highest concentrations of M. spicata and M. longifolia EOs on MDA, TPC, TFC, and PC level in L. esculentum seedling under Fusarium root rot disease infection. Bars with different letters indicate significant differences between treatments at $p \leq 0.05$. Data are expressed as the mean of three replicates \pm SDs. 


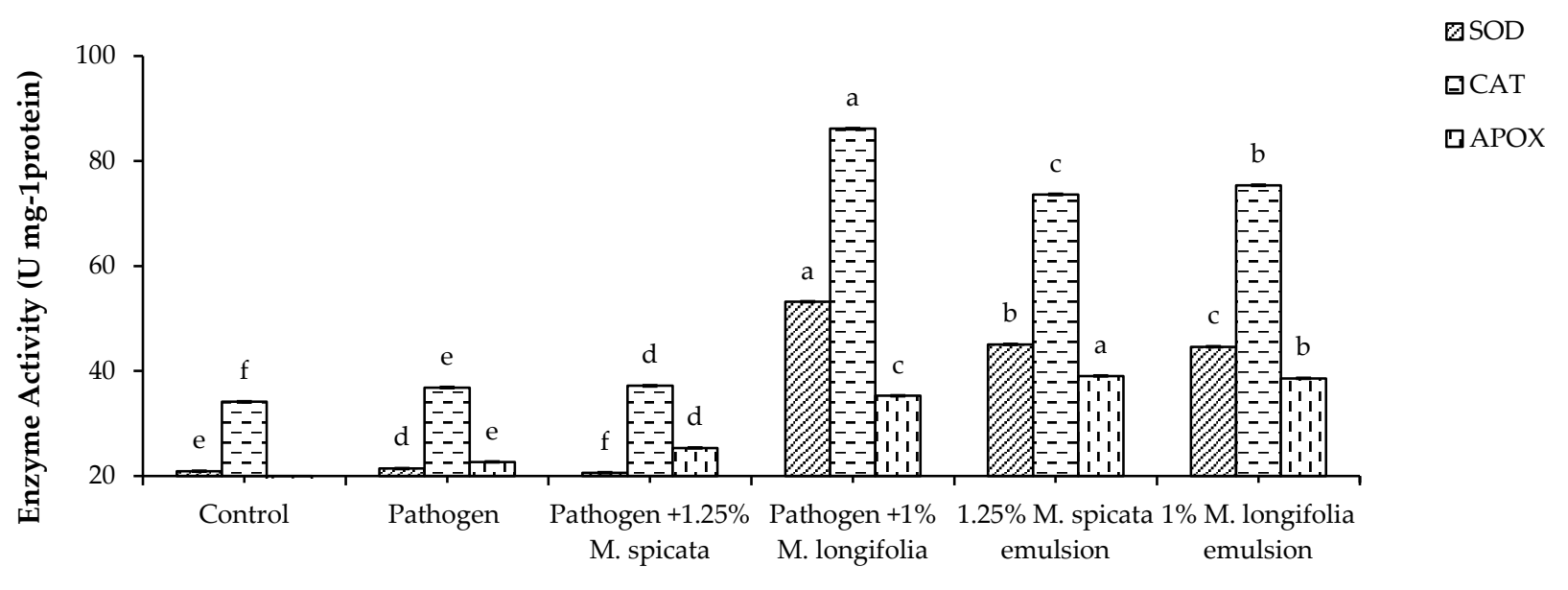

Figure 8. Effects of M. spicata and M. longifolia EOs on SOD, CAT, and APOX activity in L. esculentum seedling under Fusarium root rot disease infection. Bars with different letters indicate significant differences between treatments at $p \leq 0.05$. Data are expressed as the mean of three replicates \pm SDs.

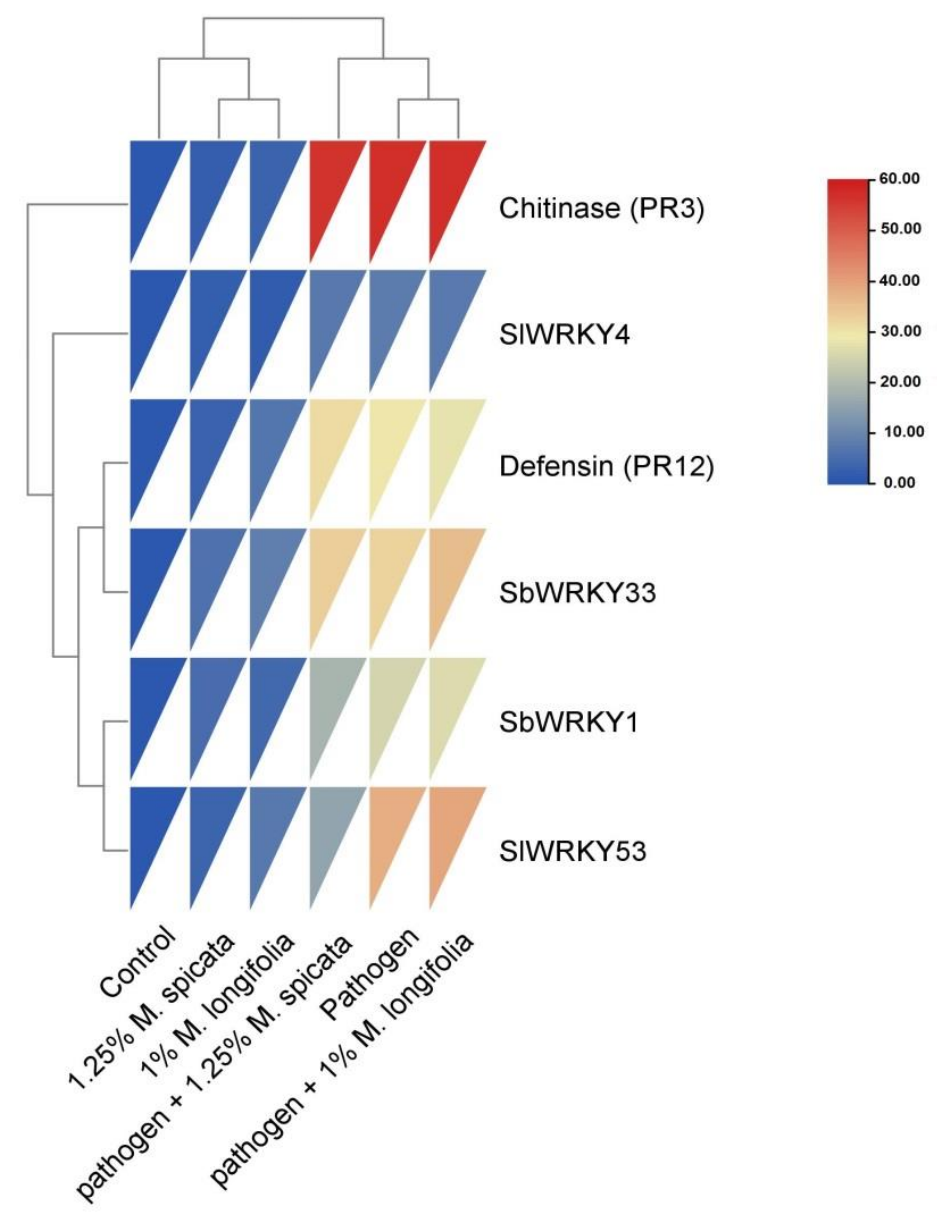

Figure 9. Hierarchical clustering heat map of relative expression levels of chitinase, defensin genes, and WRKY1, WRKY4, WRKY33, and WRKY53 transcripts in L. esculentum seedling under Fusarium injection and application of $1.25 \%$ M. spicata and $1.0 \%$ M. longifolia EOs treatments.

\section{Discussion}

F. oxysporum f. sp. radicis-lycopersici is a wide-spread fungus in the plant rhizosphere which causes Fusarium crown and root rot (FCRR) disease and leads to losses of tomato production even in greenhouses and systems of soil production [35]. There are different 
management methods for root rot disease of tomato crop using chemical and biological controls [36]. Biological control for pathogenic fungi is the new management trend for reducing the harmful effects of chemicals (fungicides) [37,38]. There are four types of biocontrol management: microorganisms, semi-chemical products, plant-based natural products, or living microorganisms [39-43]. Furthermore, plant EOs are effective biocontrol agents against a variety of pathogenic fungi and bacteria [44-47].

The present investigation revealed the effect of Mentha spicata and M. longifolia on EOs on root rot disease of tomato infected with F. oxysporum both in vitro and in vivo. M. spicata and M. longifolia EOs had potentiality against Fusarium. The order of efficient EOs against Fusarium pathogen was: $M$. longifolia $>M$. spicata. The highest antifungal activity was observed in the case of all concentrations of $M$. longifolia $\mathrm{EO}$ in agreement with previous studies [48]. The capability of two Mentha EOs against fusarium is due to the ability of bioactive chemical molecules to penetrate the fungal cell wall and cytoplasmic membrane and destroy mitochondrial membranes [49]. Plant EOs contributed to loss of rigidity of the hyphal cell wall as well as damaging the cellular enzyme system, resulting in cell death [50,51]. Many other studies reported that the antifungal activity of M. spicata EO against F. oxysporum and Aspergillus niger depends on the chemical constituents: menthol, thymol, and piperitone, individually or in synergic effect $[52,53]$. Thymol compound activity presented in the malformation of the cellular membrane in addition to inhibition for ATPase activity [43,54]; regarding the effect of thymol and eugenol, they correlated to the ability of thymol compounds' lysis of the external membrane of microorganisms which facilitated the entrance of eugenol to cytoplasm and interacted with protein $[44,53]$. Krishna Kishore et al. [55] demonstrated the antifungal activity of carvacrol, -terpineol, terpinen-4-ol, and linalool against Rhizoctonia solani, F. oxysporum, Penicillium digitatum, A. niger, Alternaria alternate, and A. flavus; these produce an effect against different microbial cells due to the ability of these compounds to penetrate the cell membrane, inactivate the enzyme pathway, and disturb their active transport [56,57].

The biological effect of the studied EOs on physiological parameters of tomato seedling is due to the presence of terpenes, alcohols, and phenolic compounds [55,58-60]. Moreover, the infected plants treated with $M$. longifolia EO showed the highest values of plant height $(19.86 \mathrm{~cm})$, shoot fresh weight $(13.64 \mathrm{~g})$, shoot dry weight $(1.85 \mathrm{~g})$, root fresh weight $(1.41 \mathrm{~g})$, and root dry weight $(0.14 \mathrm{~g})$. The main components in $M$. spicata, adipic acid $25.82 \%$ and piperitone $24.76 \%$, are different than their percentage in $M$. spicat $a$ EO as reported by Bayan and Küsek [61]. Chemical constituents for M. longifolia EO were d-limonene, menthol, menthyl acetate, linalool, and eugenol, with percentages that differ from those reported from GC-MS analysis conducted by Desam et al. [62]. This difference in the percentage of single constituents for Mentha EOs may be due to differences in extraction methods or genetic diversity of these plants [63].

Menthol, menthyl acetate, linalool, and eugenol constituents alter cell permeability for Fusarium fungi and cause plasmolysis and cell death [64]. This study recorded collapsing of mycelium hyphae for F. oxysporum f. sp. lycopersici treated with EOs of M. spicata and M. longifolia with potential activity as biological control and therapeutic effect against root rot disease.

To analyze the role of chitinase, defensin, WRKY1, WRKY4, WRKY33, and WRKY53 transcripts in L. esculentum plant defense against $F$. oxysporum fungal pathogen, we analyzed their expression after pathogen infection, and pathogen infection and application of $1.25 \%$ M. spicata and $1.0 \%$ M. longifolia EOs treatments. The expression results showed over-expression by 57.24 fold and changes in the level of WRKY33 transcription factor were recorded in infected plants treated with $1.0 \%$ M. longfolia, followed with 57.16 and 56.4 fold changes in pathogen, and $1.25 \%$ M. spicata treatments, respectively, while minimum expression of WRKY33 2.43 fold was observed with $1.25 \%$ M. spicata EO compared with control. The expression profile of WRKY35 TF revealed a significant upregulation of 39.23 and 38.12 fold changes at the pathogen-infected plant under $1.0 \%$ M. longfolia and pathogen treatments, respectively, and the minimum fold change of 3.52 was at $1.25 \%$ 
M. spicata EO compared with control. Data obtained in this study showed upregulation in the WRKY4 TF expression of 37.65 and 32.95 change folds at the pathogen-infected plant under $1.0 \%$ M. longfolia and pathogen treatments, respectively. In comparison, WRKY1 TF expression patterns were 26.35 and 25.17 change folds at the pathogen-infected plant under $1.0 \% \mathrm{M}$. longfolia and pathogen treatments, respectively, as compared with minimum expression level of 4.23 folds with $1.0 \% \mathrm{M}$. longfolia. Our results were in agreement with previous studies which reported that WRKY3 and WRKY4 encode two structurally similar WRKY proteins, and their expression was responsive to stress conditions. Stress-induced expression of WRKY4 but not WRKY3 was further enhanced by pathogen infection. These results strongly suggest that WRKY4 regulates crosstalk between SA and JA/ET-mediated signaling pathways and, as a result, plays opposite roles in resistance to the two different types of microbial pathogens. Interestingly, WRKY proteins such as WRKY4, WRKY33, and redundant WRKY18, WRKY40, and WRKY60 play a positive role in plant resistance to necrotrophic pathogens.

The expression of defense-related genes showed over-expression under pathogen infection conditions and with the pathogen under $1.0 \%$ of $M$. longfolia and $1.25 \%$ of M. spicata. In contrast, chitinase gene was upregulated with 31.25, 29.6, and 27.83 fold changes at pathogen with $1.25 \%$ M. spicata, pathogenated plants, and then pathogenated with $1.0 \% \mathrm{M}$. longfolia treatments, respectively. In addition, defensin gene expressed as $18.65,16.16$, and 15.76 fold changes at pathogen with $1.0 \%$ M. longfolia, pathogen with $1.25 \%$ M. spicata, and pathogen treatments compared with minimum 2.44 fold expression was recorded at $1.25 \%$ M. spicata EO treatment.

These results collectively indicate that overexpression of chitinase, defensin, and WRKY transcripts play a positive role in inducing plant resistance against F. oxysporum and working toward reducing disease severity. Additionally, WRKY transcripts and PR3, PR12 genes were further enhanced by pathogen infection, and they are already considered as a marker for the plant-microbe interaction.

WRKY family members have diverse regulatory mechanisms; their protein can be effectively combined with $\mathrm{W}$-box elements and bind to acting elements to activate or inhibit the transcription of downstream target genes through the cis-acting mechanism [65]. Thus, WRKY as a transcription factor plays an important role in plant defense in response to attacks by several pathogens. The response works by activating the expression of resistance genes directly or indirectly. It has been reported that WRKY DNA binding proteins bind to the promoter region of Arabidopsis natriuretic peptide receptor 1 (NPR1), which activated the plant defense system [66]. Moreover, WRKY33 activates the plant resistance system against necrotrophic fungi Alternaria brassicicola and Botrytis cinerea [29], and it can regulate the SAR system in the infected plants and also the PR genes [67,68]. Moreover, the high expression of such transcription factors could regulate the plant pathogen sensitivity to mutants of AtWRKY4, AtWRKY3, and AtWRKY3 WRKY4, increasing the plant susceptibility toward the fungus $B$. cinerea. In contrast, the high expression of the non-mutated AtWRKY4 enhanced the plant's resistance toward the Pseudomonas syringae [69]. Many plant WRKY genes are induced by biotrophic and necrotrophic pathogens, including fungi and viruses, through the induction of SA-dependent SAR and PR genes [70,71].

\section{Materials and Methods}

\subsection{Sample Collection, Identification, and Preparation}

\subsubsection{Fungal Isolate and Tomato Variety}

The studied Fusarium oxysporum isolate was investigated as an aggressive fungal pathogen in tomato and other plants and was deposited in GenBank under accession number (KJ831189) and obtained from the Department of Plant Protection and Biomolecular Diagnosis, Arid Lands Cultivation Research Institute, Alexandria (Egypt). The fungal isolate was maintained on potato dextrose agar (PDA) slants and stored at $4{ }^{\circ} \mathrm{C}$ until further bioassay. Tomato seed (super strain B) variety was obtained from the Egyptian Ministry of Agriculture. 


\subsubsection{Medicinal Plant Materials}

Leaves of M. spicata and M. longifolia were collected from unrestricted habitats, Alexandria (Egypt), in June 2020. The plants' identification was performed in the Botany Department, Faculty of Science, Mansoura University, Mansoura (Egypt).

\subsection{Extraction of Essential Oils}

Previously collected M. spicata and M. longifolia healthy fresh leaves at age one month were prewashed with tap water, disinfected with $2 \%$ sodium hypochlorite for $30 \mathrm{~min}$, then rinsed with sterile distilled water. Air-dried plant leaves were homogenized to a fine powder in a mill, stored in airtight dark bottles, and kept until use. Leaf powders were subjected to hydrodistillation for $3 \mathrm{~h}$ using a Clevenger-type apparatus, Shiva Scientific Glass Pvt. Ltd., New Delhi, India [72].

\subsection{GC-MS of Essential Oils}

The chemical composition of the volatile content of two studied EOs was determined using GC-MS- QP2010 Ultra analysis system (Shimadzu, Tokyo, Japan). Compounds were separated on an Inc DB-5 $60 \mathrm{~m} \times 0.25 \mathrm{~mm} / 0.25$ micron column (Agilent Technologies, Santa Clara, CA, USA). The oven temperature program was initiated at $50{ }^{\circ} \mathrm{C}$, held for $3 \mathrm{~min}$, then increased at rate of $8{ }^{\circ} \mathrm{C}$ to $250^{\circ} \mathrm{C} \mathrm{min}^{-1}$ and held for $10 \mathrm{~min}$. The spectrophotometer was operated in electron impact mode. The injector, interface, and ion source were kept at $250{ }^{\circ} \mathrm{C}, 250{ }^{\circ} \mathrm{C}$, and $220^{\circ} \mathrm{C}$, respectively. Split injection $(1 \mu \mathrm{L}$ diluted sample in n-hexane $(1: 1, v / v)$ injected) was conducted with a split ratio of $1: 20$ and column flow of $1.5 \mathrm{~mL} / \mathrm{min}$, and helium was the carrier gas.

Identification of the components of the sample was based on a comparison of their relative indices and mass spectra by computer matching with WILEY and National Institute of Standards and Technology (NIST08) libraries data (http:/ / webbook.nist.gov accessed on 20 November 2021) provided with the computer controlling GC-MS system. Individual isolated compound identifications were also performed by comparing their mass spectra and retention times with authentic compounds and literature data [73].

\subsection{Preparation of EOs}

The M. spicata and M. longifolia EOs colloid solutions were prepared by slowly adding $20 \mathrm{~mL}$ of M. spicata and M. longifolia EOs to $1 \mathrm{~mL}$ of non-ionic surfactant Tween $80(1 \%)$, and the dispersion was performed under gentle stirring. Then, $80 \mathrm{~mL}$ of distilled water was added to reach the final mixture of $100 \%$ with continuous stirring using a magnetic stirrer for $30 \mathrm{~min}$. The mixture was fed into a liquefied potato dextrose medium at different concentrations for further in vitro antifungal activity assay and greenhouse experiments.

\subsection{In Vitro Antifungal Activity of EOs}

Assessment of the antifungal activity of $M$. spicata and M. longifolia EOs were conducted in vitro and evaluated against $F$. oxysporum radial mycelial growth using the agar plate technique according to Tatsadjieu et al. [74]. The M. spicata and M. longifolia EOs were liquefied in sterilized PDA media to obtain a final concentration of $0.25 \%, 0.5 \%, 0.75 \%, 1.0 \%$ and $1.25 \%$. Twenty $\mathrm{mL}$ of broth medium was poured into Petri dishes ( $90 \mathrm{~mm}$ diameter). Plates supplemented with $0.05 \%$ of fungicide (nystatin at $0.5 \mu \mathrm{L} / \mathrm{mL}$ ) were used as control. Sterile distilled water was used in the bioassays instead of EO as a negative control. All plates were inoculated with mycelial disc ( $5 \mathrm{~mm}$ diameter) of F. oxysporum from the PDA plate margins (5-7 days old). Three replicate plates were used for each treatment. Then, the Petri-dishes were incubated at $25^{\circ} \mathrm{C}$ and the fungal colony diameter was measured at 7 days.

\subsection{Preparation of Fungal Suspension}

The fungal suspension was prepared as follows: five discs ( $5 \mathrm{~mm}$ diameter) of mycelia agar plugs (7 days old) were added to $1 \mathrm{~kg}$ of sterilized maize grains, sand (2:1 $v / v)$. Ten $\mathrm{mL}$ 
of sterile water was added to the last mixture in a $2 \mathrm{~L}$ flask and incubated at $25 \pm 2{ }^{\circ} \mathrm{C}$ for two weeks. After that, the mixture was put into plastic pots $(20 \mathrm{~cm}$ diameter $)$. Five sterile discs of PDA medium were inoculated into a control flask [75].

\subsection{Greenhouse Experiments}

Seeds of tomato were surface sterilized in sodium hypochlorite for $30 \mathrm{~min}$, washed five times in sterile water, and germinated in peat moss for three weeks (21DAS). The experiment was irrigated regularly and subsequently moved to experimental pots. Four weeks later, tomato seedlings were removed and their roots were washed and transplanted into the $20 \mathrm{~cm}$ diameter pots filled with pasteurized sandy clay soil at $0.9 \mathrm{~kg}$ per pot. The seedlings were treated with $M$. spicata and M. longifolia EOs at $1.25 \%$ and $1.0 \%$, respectively, in the rhizosphere soil. Pots were arranged in a randomized complete block design with three replications. In the first experiment, the pots were divided into two main groups: untreated plants as negative control (C) and plants inoculated with F. oxysporum fungal suspension as positive control $(\mathrm{P})$. In the second experiment, after 2 weeks from inoculation, negative control was treated with $50 \mathrm{~mL}$ M. spicata EOs (1.25\%) (T1) and $50 \mathrm{~mL}$ M. longifolia EOs (1.0\%) (T2). In addition, the positive control was treated with $50 \mathrm{~mL} \mathrm{M}$. spicata EOs $(1.25 \%)(\mathrm{P}+\mathrm{T} 1)$ and $50 \mathrm{~mL}$ M. longifolia EOs (1.0\%) (P+T2). All the plants continued growth after transplantation with regular irrigation every 3 days for 2 weeks in a greenhouse at $22 / 16^{\circ} \mathrm{C}, 65-70 \%$ humidity. We then evaluated all pots for the incidence of F. oxysporum root rot.

\subsubsection{Disease Assessments}

The disease severity (DS) was evaluated using the $0-5$ scale described by Filion et al. [76]:

$$
\text { Disease severity }(\%)=\left(\sum \mathrm{ab} / \mathrm{AK}\right) \times 100
$$

where $\mathrm{a}=$ number of diseased plants with the same infection degree, $\mathrm{b}=$ infection degree, $\mathrm{A}=$ total number of the evaluated plants, and $\mathrm{K}=$ the greatest infection degree.

Whereas the disease incidence (DI) was calculated according to the following equation:

Disease incidence $(\%)=(\mathrm{a} / \mathrm{A}) \times 100$

where $\mathrm{a}=$ number of diseased plants, and $\mathrm{A}=$ total number of evaluated plants.

\subsubsection{Analysis of Plant Growth Parameters}

Tomato seedlings of 21-day samples were collected to measure morphological traits. Three plants of each experiment were harvested and transferred to the laboratory and carefully uprooted, washed using tap water for measuring plant height and shoot and root fresh weight. Shoot and root dry weight were measured after oven drying at $40{ }^{\circ} \mathrm{C}$ for $48 \mathrm{~h}$.

According to Lichtenthaler et al [77] method, chlorophyll content was determined after 35 days using spectrophotometry. The photosynthetic pigments were ground and extracted from $0.5 \mathrm{~g}$ of a third of the fully expanded plant leaves between 8:00 and 10:00 a.m., and suspended in $10 \mathrm{~mL}$ of $80 \%(v / v)$ acetone in the dark using a pestle and mortar. Extracts were filtrated and the content of total chlorophyll was determined at $645 \mathrm{~nm}$ and $663 \mathrm{~nm}$.

\subsection{Electrolytes Leakage}

Determination of electrolytes leakage was conducted by adding $200 \mathrm{mg}$ of fresh tomato leaves to a test tube containing $4 \mathrm{~mL}$ of de-mineralized water and shacked for $30 \mathrm{~min}$. It was then rinsed 3 times to eliminate surface electrolytes [78]. Malondialdehyde (MDA) content was examined in the fresh tomato leaves using the method described by Heath and Packer [79]. Briefly, the MDA contents were determined after centrifugation $(12,000 \times g)$ for $10 \mathrm{~min}$; the absorbance reading was $600 \mathrm{~nm}$ and $532 \mathrm{~nm}$ using a UV-VIS spectrometer (Jenway, Tokyo, Japan). 


\subsection{Determination of Total Phenolic and Flavonoid Contents}

Total phenolic content (TPC) of tomato was measured by dissolving $5 \mathrm{mg}$ of air-dried leaf powder in $10 \mathrm{~mL}$ methanol according to Slinkard and Singleton [80] using FolinCiocalteu reagent protocol. Total flavonoid content (TFC) of tomato leaves was evaluated using the aluminum chloride colorimetry method described by Chavan et al. [81]. A standard calibration curve was constructed using quercetin in different concentrations $(0.05-1 \mathrm{mg} / \mathrm{mL})$. Tomato extract or quercetin $(2 \mathrm{~mL})$ was mixed with $500 \mu \mathrm{L}$ of $10 \%$ aluminum chloride solution and $500 \mu \mathrm{L}$ of $0.1 \mathrm{mM}$ sodium nitrate solution. The absorbance of the reaction mixture was measured after incubation at room temperature for $30 \mathrm{~min}$ at wavelength $430 \mathrm{~nm}$ using a UV-VIS spectrometer (Jenway, Tokyo, Japan). Soluble protein content (PC) was estimated in both control and treated plants following Bradford [82] using Coomassie Brilliant Blue G-250 dye and the absorbance was recorded at $595 \mathrm{~nm}$ using bovine serum albumin as standard.

\subsection{Assay of Antioxidant Enzymes}

Antioxidant enzymes were extracted by homogenizing $1 \mathrm{gm}$ fresh tomato leaf tissue in chilled $50 \mathrm{mM}$ phosphate buffer ( $\mathrm{pH}$ 7.0) supplemented with $1 \%$ polyvinyl pyrolidine and $1 \mathrm{mM}$ EDTA using prechilled pestle and mortar. After centrifuging at $18,000 \times g$ for $30 \mathrm{~min}$ at $40{ }^{\circ} \mathrm{C}$, the supernatant was used for enzyme assay. Determination of the activity of superoxide dismutase (SOD, EC 1.15.1.1) and NBT photochemical reductions was recorded at $560 \mathrm{~nm}$ using the Bayer and Fridovich [83] method in a $1.5 \mathrm{~mL}$ assay mixture containing sodium phosphate buffer (50 mM, pH 7.5), $100 \mu \mathrm{L}$ EDTA, L-methionine, $75 \mu \mathrm{M}$ NBT, riboflavin, and $100 \mu \mathrm{L}$ enzyme extract.

The catalase assay (CAT, EC1.11.1.6) activity method of Luck [84] was used and monitored the change in absorbance at $240 \mathrm{~nm}$ for $2 \mathrm{~min}$. For the calculation, an extinction coefficient of $39.4 \mathrm{mM}^{-1} \mathrm{~cm}^{-1}$ was used. Ascorbate peroxidase (APX, EC 1.11.1.11) activity was tested by monitoring absorption change at $290 \mathrm{~nm}$ for $3 \mathrm{~min}$ in a $1 \mathrm{~mL}$ reaction mixture containing potassium phosphate buffer ( $\mathrm{pH} 7.0), 0.5 \mathrm{mM}$ ascorbic acid, hydrogen peroxide, and enzyme extract. The calculation of the extinction coefficient of $2.8 \mathrm{mM}^{-1} \mathrm{~cm}^{-1}$ was used [85].

\subsection{Gene Expression}

According to the manufacturer's protocol, total mRNA was isolated from $0.5 \mathrm{~g}$ tomato plant root of control and all treatments using the Plant RNA Kit (Sigma-Aldrich, St. Louis, MO, USA). The purified RNA was quantitated using SPECTROstar Nano (BMG LABTECH, Ortenberg, Germany). For each sample, $10 \mu \mathrm{g}$ total RNA was treated with DNAse RNAsefree (Fermentas, Waltham, MA, USA), $5 \mu \mathrm{g}$ of which was reverse transcribed in a reaction mixture consisting of oligo dT primer $(10 \mathrm{pmL} / \mu \mathrm{L}), 2.5 \mu \mathrm{L} 5 \mathrm{X}$ buffer, $2.5 \mu \mathrm{L} \mathrm{MgCl} 2,2.5 \mu \mathrm{L}$ $2.5 \mathrm{mM}$ dNTPs, $4 \mu \mathrm{L}$ from oligo $(\mathrm{dT}), 0.2 \mu \mathrm{L}$ (5 Unit/ $\mu \mathrm{L}$ ) reverse transcriptase (Promega, Walldorf, Germany), and $2.5 \mu \mathrm{L}$ RNA. RT-PCR amplification was performed in a thermal cycler PCR, programmed at $42{ }^{\circ} \mathrm{C}$ for $1 \mathrm{~h}$ and $72{ }^{\circ} \mathrm{C}$ for $20 \mathrm{~min}$. Quantitative real-time PCR was carried out on $1 \mu \mathrm{L}$ 1:10 diluted cDNA templates by triplicate using the realtime analysis (Rotor-Gene 6000, QIAGEN GmbH, Hilden, Germany) system. The primer sequences used in qRT-PCR are given in Table 4. Primers of three PRs (PR3, PR12) genes, three WRKY transcriptional factors (WRKY1, WRKY4, WRKY33, and WRKY53 TFs genes), and housekeeping gene (reference gene) were used for gene expression analysis using SYBR $^{\circledR}$ Green-based method. The reaction mixture consists of $1 \mu \mathrm{L}$ of template, $10 \mu \mathrm{L}$ of SYBR Green Master Mix, $2 \mu \mathrm{L}$ of reverse primer, $2 \mu \mathrm{L}$ of forwarding primer, and sterile distilled water for a total reaction volume of $20 \mu \mathrm{L}$. PCR assays were performed using the following conditions: $950{ }^{\circ} \mathrm{C}$ for $15 \mathrm{~min}$ followed by 40 cycles of $950{ }^{\circ} \mathrm{C}$ for $30 \mathrm{~s}$ and $600{ }^{\circ} \mathrm{C}$ for $30 \mathrm{~s}$. The $\mathrm{CT}$ of each sample was used to calculate $\triangle \mathrm{CT}$ values (target gene CT subtracted from $\beta$-Actin gene CT [86]). The relative gene expression was determined using the 2- $\Delta \Delta \mathrm{Ct}$ method [87]. 
Table 4. Sequences of primers used in qRT-PCR analysis.

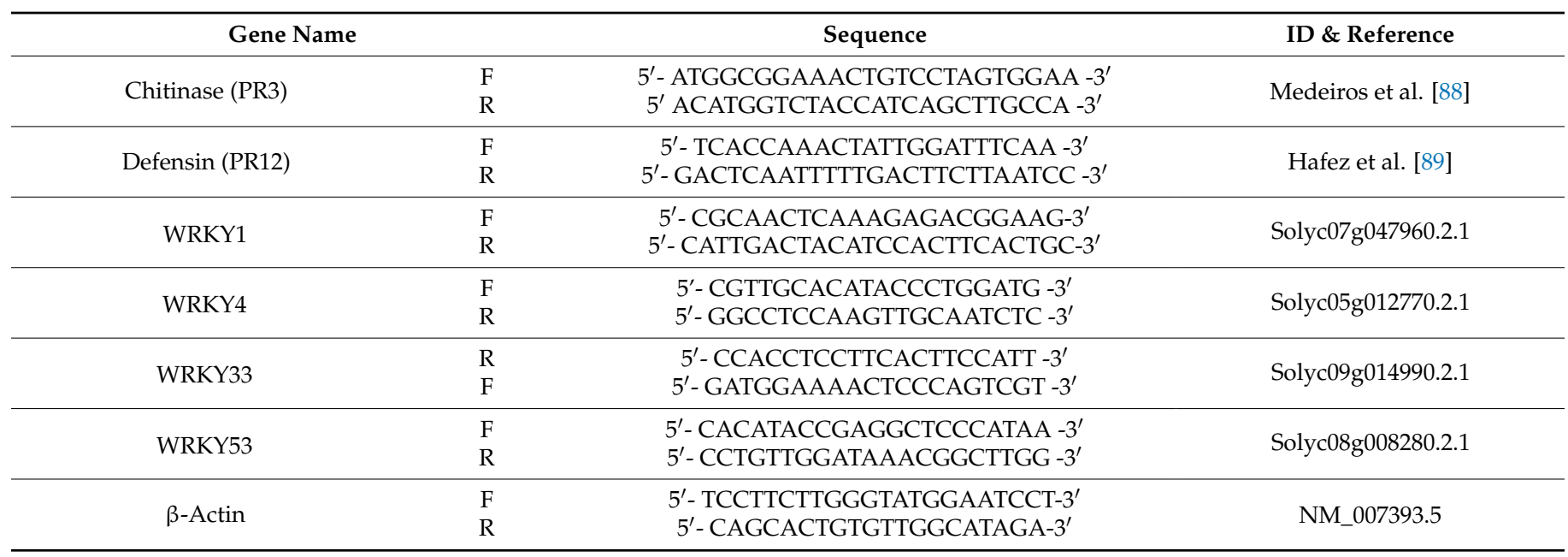

\subsection{Statistical Analyses}

All the experiments were performed in triplicates. Obtained data and results were expressed as mean \pm standard deviation $( \pm S D)$. Some experiments were arranged in a completely randomized blocks design and data were statistically analyzed by one-way ANOVA test using SPSS 16 . The probability values $p \leq 0.05$ were considered statistically significant based on Duncan's least significant difference test. The heatmap was constructed to study the similarity and dissimilarity among studied taxa based on essential and nonessential amino acids using the TBtools package [90].

\section{Conclusions}

We can conclude that EOs of two Mentha aromatic plants (M. spicata and M. longifolia) have the highest potential against Fusarium root rot disease for tomatoes. The chemical essential oils of these EOs have a lethal effect against F. oxysporum fungi. In addition, these EOs enhance the growth of tomato plants by increasing their physiological activities. Due to the pathogen attack, this activity could be induced by the plant defense system. This activity was regulated by different families of genes such as WRKY and PR proteins. On the other hand, L. esculentum seed priming or seedling root treatments with M. spicata and M. longifolia EOs could be used at lower concentrations (1.0-1.25\%) to enhance seedling growth and alleviate the adverse effects of the fungal disease by supporting antioxidant enzymes and total phenols accumulation which could help make seeds or plants tolerate oxidative stress conditions further. Finally, the EOS of Mentha medicinal plants can be used as a safe alternative to fungicides that improve the growth of the infected plant without defects in plant and human health.

Supplementary Materials: The following supporting information can be downloaded at: https: / / www.mdpi.com/article/10.3390/plants11020189/s1, Figure S1. Relative expression level of WRKY1 gene in S. lycopersicum seedling under Fusarium inoculation and application of M. spicata and $M$. longifolia EOs. Different letters indicate significant differences between different treatments at $p \leq 0.05$. Figure S2. Relative expression level of WRKY4 gene in S. lycopersicum seedling under Fusarium inoculation and application of M. spicata and M. longifolia EOs. Different letters indicate significant differences between different treatments at $p \leq 0.05$. Figure S3. Relative expression level of WRKY33 gene in S. lycopersicum seedling under Fusarium inoculation and application of M. spicata and $M$. longifolia EOs. Different letters indicate significant differences between different treatments at $p \leq 0.05$. Figure S4. Relative expression level of WRKY53 gene in S. lycopersicum seedling under Fusarium inoculation and application of M. spicata and M. longifolia EOs. Different letters indicate significant differences between different treatments at $p \leq 0.05$. Figure S5. Relative expression level of Chitinase gene in S. lycopersicum seedling under Fusarium inoculation and application of M. spicata and $M$. longifolia EOs. Different letters indicate significant differences between different treatments at $p \leq 0.05$. 
Figure S6. Relative expression level of defensin gene in S. lycopersicum seedling under Fusarium inoculation and application of M. spicata and M. longifolia EOs. Different letters indicate significant differences between different treatments at $p \leq 0.05$.

Author Contributions: Conceptualization, S.A.S., E.E.H. and E.-S.S.A.R. and A.A.I.; data curation, E.-S.S.A.R., S.S.A.K., A.A.I. and H.S.E.; formal analysis, E.E.H., S.A.-E. and A.A.I.; investigation, S.A.S.; methodology, E.-S.S.A.R., S.A.-E. and A.A.I.; resources, E.E.H., E.-S.S.A.R. and A.A.I.; software, A.M.G.A.-K. and E.-S.S.A.R.; supervision, E.E.H. and H.S.E.; validation, E.E.H., S.S.A.K. and H.S.E.; visualization, S.A.S., A.M.G.A.-K., E.-S.S.A.R., S.A.-E. and A.A.I.; and writing-review and editing, A.A.I. All authors have read and agreed to the published version of the manuscript.

Funding: This research received no external funding.

Institutional Review Board Statement: Not applicable.

Informed Consent Statement: Not applicable.

Data Availability Statement: Relevant data applicable to this research are within the paper.

Conflicts of Interest: The authors declare no conflict of interest.

\section{References}

1. Gupta, S.; Rashotte, A.M. Expression patterns and regulation of SICRF3 and SICRF5 in response to cytokinin and abiotic stresses in tomato (Solanum lycopersicum). J. Plant Physiol. 2014, 171, 349-358. [CrossRef] [PubMed]

2. Bergougnoux, V. The history of tomato: From domestication to biopharming. Biotechnol. Adv. 2014, 32, 170-189. [CrossRef] [PubMed]

3. Panthee, D.R.; Chen, F. Genomics of fungal disease resistance in tomato. Curr. Genom. 2010, 11, 30-39. [CrossRef] [PubMed]

4. Rongai, D.; Pulcini, P.; Pesce, B.; Milano, F. Antifungal activity of pomegranate peel extract against fusarium wilt of tomato. Eur. J. Plant Pathol. 2017, 147, 229-238. [CrossRef]

5. $\quad$ Asha, B.B.; Nayaka, C.S.; Shankar, U.A.; Srinivas, C.; Niranjana, S.R. Biological control of F. oxysporum f. sp. lycopersici causing wilt of tomato by Pseudomonas fluorescens. Int. J. Microbiol. Res. 2011, 3, 79-84.

6. Pandey, K.K.; Gupta, R.C. Pathogenic and cultural variability among Indian isolates of Fusarium oxysporum f. sp. lycopersici causing wilt in tomato. Indian Phytopathol. 2014, 67, 383-387.

7. Kirankumar, R.; Jagadeesh, K.S.; Krishnaraj, P.U.; Patil, M.S. Enhanced growth promotion of tomato and nutrient uptake by plant growth promoting rhizobacterial isolates in presence of tobacco mosaic virus pathogen. Karnataka J. Agric. Sci. 2010, 21, 309-311.

8. Singh, V.K.; Singh, H.B.; Upadhyay, R.S. Role of fusaric acid in the development of 'Fusarium wilt' symptoms in tomato: Physiological, biochemical and proteomic perspectives. Plant Physiol. Biochem. 2017, 118, 320-332. [CrossRef]

9. Bhat, R.; Rai, R.V.; Karim, A.A. Mycotoxins in food and feed: Present status and future concerns. Compr. Rev. Food Sci. Saf. 2010, 9 , 57-81. [CrossRef]

10. Gulluce, M. Antimicrobial and antioxidant properties of the essential oils and methanol extract from Mentha longifolia L. ssp. Longifolia. Food Chem. 2007, 103, 1449-1456. [CrossRef]

11. Moghaddam, M.; Pourbaige, M.; Tabar, H.K.; Farhadi, N.; Hosseini, S.M.A. Composition and antifungal activity of peppermint (Mentha piperita) essential oil from Iran. J. Essent. Oil Bear. Plants 2013, 16, 506-512. [CrossRef]

12. Hussain, A.I.; Anwar, F.; Nigam, P.S.; Ashraf, M.; Gilani, A.H. Seasonal variation in content, chemical composition and antimicrobial and cytotoxic activities of essential oils from four Mentha species. J. Sci. Food Agric. 2010, 90, 1827-1836. [CrossRef]

13. Della Pepa, T.; Elshafie, H.S.; Capasso, R.; De Feo, V.; Camele, I.; Nazzaro, F.; Scognamiglio, M.R.; Caputo, L. Antimicrobial and phytotoxic activity of Origanum heracleoticum and O. majorana essential oils growing in cilento (Southern Italy). Molecules 2019, 24, 2576. [CrossRef]

14. Sonam, K.A.; Kumar, V.; Guleria, I.; Sharma, M.; Kumar, A.; Alruways, M.W.; Khan, N.; Raina, R. Antimicrobial Potential and Chemical Profiling of Leaves Essential Oil of Mentha Species Growing under North-West Himalaya Conditions. J. Pure Appl. Microbiol. 2021, 15, 2229-2243. [CrossRef]

15. Rizwana, H.; Alwhibi, M.S. Biosynthesis of silver nanoparticles using leaves of Mentha pulegium, their characterization, and antifungal properties. Green Process Synth. 2021, 10, 824-834. [CrossRef]

16. Hajlaoui, H.; Trabels, N.; Noumi, E. Biological activities of the essential oils and methanol extract of two cultivated mint species (Mentha logifolia and Mentha pulegium) used in the Tunisian folkloric medicine. World J. Microbiol. Biotechnol. 2009, 25, 2227-2238. [CrossRef]

17. Singh, Y.R.; Sandeep, K.; Anupam, D. Antifungal properties of essential oil Mentha spicata 1. var. MSS-5. Indian J. Crop Sci. 2006, 1 , 197-200.

18. Kadoglidou, K.; Chatzopoulou, P.; Maloupa, E.; Kalaitzidis, A.; Ghoghoberidze, S.; Katsantonis, D. Mentha and Oregano Soil Amendment Induces Enhancement of Tomato Tolerance against Soilborne Diseases, Yield and Quality. Agronomy 2020, 10, 23. [CrossRef] 
19. Brahmi, F.; Adjaoud, A.; Marongiu, B.; Porcedda, S.; Piras, A.; Falconieri, D.; Yalaoui-Guellal, D.; Elsebai, M.F.; Madani, K.; Chibane, M. Chemical composition and in vitro antimicrobial, insecticidal and antioxidant activities of the essential oils of Mentha pulegium L. and Mentha rotundifolia (L.) Huds growing in Algeria. Ind. Crops Prod. 2016, 88, 96-105. [CrossRef]

20. Silva, C.L.; Câmara, J.S. Profiling of volatiles in the leaves of Lamiaceae species based on headspace solid phase microextraction and mass spectrometry. Food Res. Int. 2013, 51, 378-387. [CrossRef]

21. Bayan, Y.; Aksit, H. Antifungal activity of volatile oils and plant extracts from Sideritis germanicopolitana BORNM growing in Turkey. Egypt J. Biol. Pest Control 2016, 26, 333-337.

22. Kumar, P.; Mishra, S.; Malik, A.; Satya, S. Insecticidal properties of Mentha species: A review. Ind. Crops Prod. 2011, 34, 802-817. [CrossRef]

23. Al-Harbi, N.A.; Al Attar, N.M.; Hikal, D.M.; Mohamed, S.E.; Abdel Latef, A.A.H.; Ibrahim, A.A.; Abdein, M.A. Evaluation of insecticidal effects of plants essential oils extracted from basil, black seeds and lavender against Sitophilus oryzae. Plants 2021, 10, 829. [CrossRef]

24. Sharma, A.; Rajendran, S.; Srivastava, A.; Sharma, S.; Kundu, B. Antifungal activities of selected essential oils against Fusarium oxysporum f. sp. lycopersici 1322, with emphasis on Syzygium aromaticum essential oil. J. Biosci. Bioeng. 2017, 123, 308-313. [CrossRef]

25. Ben-Jabeur, M.; Ghabri, E.; Myriam, M.; Hamada, W. Thyme essential oil as a defense inducer of tomato against gray mold and Fusarium wilt. Plant Physiol. Biochem. 2015, 94, 35-40. [CrossRef]

26. De Vos, M.; Van Oosten, V.R.; Van Poecke, R.M.; Van Pelt, J.A.; Pozo, M.J.; Mueller, M.J.; Pieterse, C.M. Signal signature and transcriptome changes of Arabidopsis during pathogen and insect attack. Mol. Plant Microbe Interact. 2005, 18, 923-937. [CrossRef]

27. Zhang, Z.; Liu, W.; Qi, X.; Liu, Z.; Xie, W.; Wang, Y. Genome-wide identification, expression profiling, and SSR marker development of the bZIP transcription factor family in Medicago truncatula. Biochem. Syst. Ecol. 2015, 61, 218-228. [CrossRef]

28. Nan, H.; Li, W.; Lin, Y.; Gao, L. Genome-Wide Analysis of WRKY genes and their response to salt stress in the wild progenitor of Asian cultivated rice, Oryza rufipogon. Front. Genet. 2020, 11, 359. [CrossRef]

29. Zhang, Y.; Wang, L. The WRKY transcription factor superfamily: Its origin in eukaryotes and expansion in plants. BMC Evol. Biol. 2005, 5, 1. [CrossRef]

30. Wen, F.; Zhu, H.; Li, P.; Jiang, M.; Mao, W.; Ong, C.; Chu, Z. Genome-wide evolutionary characterization and expression analyses of WRKY family genes in Brachypodium distachyon. DNA Res. 2014, 21, 327-339. [CrossRef]

31. Guo, C.; Guo, R.; Xu, X.; Gao, M.; Li, X.; Song, J.; Zheng, Y.; Wang, X. Evolution and expression analysis of the grape (Vitis vinifera L.) WRKY gene family. J. Exp. Bot. 2014, 65, 1513-1528. [CrossRef] [PubMed]

32. Meng, X.; Zhang, S. MAPK cascades in plant disease resistance signaling. Ann. Rev. Phytopathol. 2013, 51, 245-266. [CrossRef] [PubMed]

33. Zheng, Z.; Qamar, S.A.; Chen, Z.; Mengiste, T. Arabidopsis WRKY33 transcription factor is required for resistance to necrotrophic fungal pathogens. Plant J. 2006, 48, 592-605. [CrossRef] [PubMed]

34. Li, G.; Meng, X.; Wang, R.; Mao, G.; Han, L.; Liu, Y.; Zhang, S. Dual-level regulation of ACC synthase activity by MPK3/MPK6 cascade and its downstream WRKY transcription factor during ethylene induction in Arabidopsis. PLoS Genet. 2012, 8, 1002767. [CrossRef]

35. Szczechura, W.; Staniaszek, M.; Habdas, H. Fusarium oxysporum F. sp. Radicis lycopersici-The cause of fusarium crown and root rot in tomato cultivation. J. Plant Protec. Res. 2013, 53, 172-176. [CrossRef]

36. Ozbay, N.; Newman, S.E. Fusarium crown and root rot of tomato and control methods. Plant Pathol. J. 2004, 3, 9-18. [CrossRef]

37. Cosentino, C.; Labella, C.; Elshafie, H.S.; Camele, I.; Musto, M.; Paolino, R.; Freschi, P. Effects of different heat treatments on lysozyme quantity and antimicrobial activity of jenny milk. J. Dairy Sci. 2016, 99, 5173-5179. [CrossRef]

38. Elshafie, H.S.; Viggiani, L.; Mostafa, M.S.; El-Hashash, M.A.; Bufo, S.A.; Camele, I. Biological activity and chemical identification of ornithine lipid produced by Burkholderia gladioli pv. agaricicola ICMP 11096 using LC-MS and NMR analyses. J. Biol. Res. 2017, 90, 96-103. [CrossRef]

39. Ravensberg, W. Crop protection in 2030: Towards a natural, efficient, safe and sustainable approach. In Proceedings of the IBMA International Symposium, Swansea University, Swansea, UK, 7-9 September 2015.

40. Camele, I.; Elshafie, H.S.; Caputo, L.; Sakr, S.H.; De Feo, V. Bacillus mojavensis: Biofilm formation and biochemical investigation of its bioactive metabolites. J. Biol. Res. 2019, 92, 39-45. [CrossRef]

41. Elshafie, H.S.; Devescovi, G.; Venturi, V.; Camele, I.; Bufo, S.A. Study of the regulatory role of N-acyl homoserine lactones mediated quorum sensing in the biological activity of Burkholderia gladioli pv. agaricicola causing soft rot of Agaricus spp. Front. Microbiol. 2019, 10, 2695. [CrossRef]

42. Sofo, A.; Elshafie, H.S.; Scopa, A.; Mang, S.M.; Camele, I. Impact of airborne zinc pollution on the antimicrobial activity of olive oil and the microbial metabolic profiles of Zn-contaminated soils in an Italian olive orchard. J. Trace Elem. Med. Biol. 2018, 49, 276-284. [CrossRef]

43. Elshafie, H.S.; Racioppi, R.; Bufo, S.A.; Camele, I. In vitro study of biological activity of four strains of Burkholderia gladioli pv. agaricicola and identification of their bioactive metabolites using GC-MS. Saudi J. Biol. Sci. 2017, 24, 295-301. [CrossRef]

44. Raveau, R.; Fontaine, J.; Lounès-Hadj Sahraoui, A. Essential oils as potential alternative biocontrol products against plant pathogens and weeds: A Review. Foods 2020, 9, 365. [CrossRef] 
45. Elshafie, H.S.; Caputo, L.; De Martino, L.; Grul'ová, D.; Zheljazkov, V.D.; De Feo, V.; Camele, I. Biological investigations of essential oils extracted from three Juniperus species and evaluation of their antimicrobial, antioxidant and cytotoxic activities. J. Appl. Microbiol. 2020, 129, 1261-1271. [CrossRef]

46. Camele, I.; Grul'ová, D.; Elshafie, H.S. Chemical composition and antimicrobial properties of Mentha piperita cv. 'Kristinka' essential oil. Plants 2021, 10, 1567. [CrossRef]

47. Ali, H.M.; Elgat, W.; El-Hefny, M.; Salem, M.Z.M.; Taha, A.S.; Al Farraj, D.A.; Elshikh, M.S.; Hatamleh, A.A.; Abdel-Salam, E.M. New Approach for Using of Mentha longifolia L. and Citrus reticulata L. Essential Oils as Wood-Biofungicides: GC-MS, SEM, and MNDO Quantum Chemical Studies. Materials 2021, 14, 18. [CrossRef]

48. Ragab, M.M.M.; Ashour, A.M.A.; Abdel-Kader, M.M.; ElMohamady, R.; Abdel-Aziz, A. In vitro evaluation of some fungicides alternatives against Fusarium oxysporum the causal of wilt disease of pepper (Capsicum annum L.). Int. J. Agric. For. 2012, 2, 70-77.

49. Arnal-Schnebelen, B.; Hadji-Minaglou, F.; Peroteau, J.F.; Ribeyre, F.; de Billerbeck, V.G. Essential oils in infectious gynaecological disease: A statistical study of 658 cases. Int. J. Aromatherapy. 2004, 14, 192-197. [CrossRef]

50. Sharma, N.; Tripathi, A. Effects of Citrus sinensis (L.) Osbeck epicarp essential oil on growth and morphogenesis of Aspergillus niger Van Tieghem. Microbiol. Res. 2008, 163, 337-344. [CrossRef]

51. Camele, I.; Elshafie, H.S.; De Feo, V.; Caputo, L. Anti-quorum sensing and antimicrobial effect of Mediterranean plant essential oils against phytopathogenic bacteria. Front. Microbiol. 2019, 10, 2619. [CrossRef]

52. Regmi, S.; Jha, S.K. Antifungal activity of plant essential oils against Fusarium oxysporum schlecht. and Aspergillus niger van tiegh. from papaya. Inter. J. Curr. Trends Sci. Tech. 2017, 8, 20196-20204.

53. Grul'ová, D.; Caputo, L.; Elshafie, H.S.; Baranová, B.; De Martino, L.; Sedlák, V.; Camele, I.; De Feo, V. Thymol chemotype Origanum vulgare L. essential oil as a potential selective bio-based herbicide on monocot plant species. Molecules 2020, 25, 595. [CrossRef]

54. Yakhlef, G.; Hambaba, L.; Pinto, D.; Silva, A.M.S. Chemical composition and insecticidal, repellent and antifungal activities of essential oil of Mentha rotundifolia (L.) from Algeria. Ind. Crops Prod. 2020, 158, 8. [CrossRef]

55. Krishna Kishore, G.; Pande, S.; Harish, S. Evaluation of essential oils and their components for broad-spectrum antifungal activity and control of late leaf spot and crown rot diseases in peanut. Plant Dis. 2007, 91, 375-379. [CrossRef]

56. Oussalah, M.; Caillet, S.; Saucier, L.; Lacroix, M. Antimicrobial effects of selected plant essential oils on the growth of a Pseudomonas putida strain isolated from meat. Meat Sci. 2006, 73, 236-244. [CrossRef]

57. Chen, C.J.; Li, Q.Q.; Zeng, Z.Y.; Duan, S.S.; Wang, W.; Xu, F.R.; Cheng, Y.X.; Dong, X. Efficacy and mechanism of Mentha haplocalyx and Schizonepeta tenuifolia essential oils on the inhibition of Panax notoginseng pathogens. Ind. Crops Prod. 2020, 145, 12. [CrossRef]

58. Elshafie, H.S.; Ghanney, N.; Mang, S.M.; Ferchichi, A.; Camele, I. An in vitro attempt for controlling severe phytopathogens and human pathogens using essential oils from Mediterranean plants of genus Schinus. J. Med. Food 2016, 19, 266-273. [CrossRef]

59. Elshafie, H.S.; Sakr, S.; Mang, S.M.; De Feo, V.; Camele, I. Antimicrobial activity and chemical composition of three essential oils extracted from Mediterranean aromatic plants. J. Med. Food. 2016, 19, 1096-1103. [CrossRef] [PubMed]

60. Burt, S. Essential oils: Their antibacterial properties and potential applications in foods a review. Int. J. Food Microbiol. 2004, 94, 223-253. [CrossRef] [PubMed]

61. Bayan, Y.; Küsek, M. Chemical composition and antifungal and antibacterial activity of Mentha spicata L. volatile oil. Cienc. Investig. Agrar. 2018, 45, 64-69. [CrossRef]

62. Desam, N.R.; Al-Rajab, A.J.; Sharma, M.; Mylabathula, M.M.; Gowkanapalli, R.R.; Albratty, M. Chemical composition, antibacterial and antifungal activities of Saudi Arabian Mentha longifolia L. essential oil. J. Coast. Life Med. 2017, 5, 441-446. [CrossRef]

63. Kumar, P.; Mishra, S.; Malik, A.; Satya, S. Compositional analysis and insecticidal activity of Eucalyptus globulus (family: Myrtaceae) essential oil against housefly (Musca domestica). Acta Trop. 2012, 122, 212-218. [CrossRef]

64. Devi, K.P.; Nisha, S.A.; Sakthivel, R.; Pandian, S.K. Eugenol (an essential oil of clove) acts as an antibacterial agent against Salmonella typhi by disrupting the cellular membrane. J. Ethnopharmacol. 2010, 130, 107-115. [CrossRef]

65. Phukan, U.J.; Jeena, G.S.; Shukla, R.K. WRKY transcription factors: Molecular regulation and stress responses in plants. Front. Plant Sci. 2016, 7, 760. [CrossRef]

66. Després, C.; Chubak, C.; Rochon, A.; Clark, R.; Bethune, T.; Desveaux, D.; Fobert, P. The Arabidopsis NPR1 disease resistance protein is a novel cofactor that confers redox regulation of DNA binding activity to the basic domain/leucine zipper transcription factor TGA1. Plant Cell 2003, 15, 2181-2191. [CrossRef]

67. Wang, D.; Amornsiripanitch, N.; Dong, X. A genomic approach to identify regulatory nodes in the transcriptional network of systemic acquired resistance in plants. PLoS Pathog. 2006, 2, 1024-1050. [CrossRef]

68. Koo, S.C.; Moon, B.C.; Kim, J.K.; Kim, C.Y.; Sung, S.J.; Kim, M.C.; Cho, M.; Cheong, Y. OsBWMK1 mediates SA-dependent defense responses by activating the transcription factor OsWRKY33. Biochem. Biophys. Res. Commun. 2009, 387, 365-370. [CrossRef]

69. Lai, Z.; Vinod, K.M.; Zheng, Z.; Fan, B.; Chen, Z. Roles of Arabidopsis WRKY3 and WRKY4 transcription factors in plant responses to pathogens. BMC Plant Biol. 2008, 8, 68. [CrossRef]

70. Dong, J.; Chen, C.; Chen, Z. Expression profile of the Arabidopsis WRKY gene superfamily during plant defense response. Plant Mol. Biol. 2003, 51, 21-37. [CrossRef]

71. Xu, X.; Chen, C.; Fan, B.; Chen, Z. Physical and functional interactions between pathogen-induced Arabidopsis WRKY18, WRKY40, and WRKY60 transcription factors. Plant Cell 2006, 18, 1310-1326. [CrossRef] 
72. Périno, S.; Chemat-Djenni, Z.; Petitcolas, E.; Giniès, C.; Chemat, F. Downscaling of industrial turbo-distillation to laboratory turbo-clevenger for extraction of essential oils. Application of concepts of green analytical chemistry. Molecules 2019, $24,2734$. [CrossRef]

73. Elshafie, H.S.; Mancini, E.; Sakr, S.; De Martino, L.; Mattia, C.A.; De Feo, V.; Camele, I. Antifungal activity of some constituents of Origanum vulgare L. essential oil against postharvest disease of peach fruit. J. Med. Food 2015, 18, 929-934. [CrossRef]

74. Tatsadjieu, N.L.; Dongmo, P.J.; Ngassoum, M.B.; Etoa, F.X.; Mbofung, C.M.F. Investigations on the essential oil of Lippia rugosa from Cameroon for its potential use as antifungal agent against Aspergillus flavus Link ex. Fries. Food Control 2009, 20, 161-166. [CrossRef]

75. Abd-El-Moity, T.H. Effect of single and mixture of Trichoderma harzianum isolates on controlling three different soil borne pathogens. Egyptian J. Microbiol. 1985, 111-120.

76. Filion, M.; St-Arnaud, M.; Jabaji-Hare, S.H. Quantification of Fusarium solani f. sp. phaseoli in mycorrhizal bean plants and surrounding mycorrhizosphere soil using real-time polymerase chain reaction and direct isolations on selective media. Phytopathology 2003, 93, 229-235. [CrossRef]

77. Lichtenthaler, H.; Wellburn, A. Determinations of total carotenoids and chlorophylls a and b of leaf extracts in different solvents. Biochem. Soc. Trans. 1983, 11, 591-592. [CrossRef]

78. Blum, A.; Ebercon, A. Cell membrane stability as a measure of drought and heat tolerance in wheat. Crop Sci. 1981, 21, 43-47. [CrossRef]

79. Heath, R.L.; Packer, L. Photoperoxidation in isolated chloroplasts. I. Kinetics and stoichiometry of fatty acid peroxidation. Arch. Biochem. Biophisics 1968, 125, 189-198. [CrossRef]

80. Slinkard, K.; Singleton, V.L. Total phenol analysis: Automation and comparison with manual methods. Am. J. Enol. Vitic. 1977, 28, 49-55.

81. Chavan, J.J.; Gaikwad, N.B.; Kshirsagar, P.R.; Dixit, G.B. Total phenolics, flavonoids and antioxidant properties of three Ceropegia species from Western Ghats of India. South Afr. J. Bot. 2013, 88, 273-277. [CrossRef]

82. Bradford, M.M. A rapid and sensitive method for the quantitation of microgram quantities of protein utilizing the principle of protein-dye binding. Anal. Biochem. 1976, 72, 248-254. [CrossRef]

83. Beyer, W.F., Jr.; Fridovich, I. Assaying for superoxide dismutase activity: Some large consequences of minor changes in conditions. Anal. Biochem. 1987, 161, 559-566. [CrossRef]

84. Bergmeyer, H.U. Methods of Enzymatic Analysis, 2nd ed.; Academic Press: New York, NY, USA, $1974 ;$ p. 855.

85. Nakano, Y.; Asada, K. Hydrogen peroxide is scavenged by ascorbate-specific peroxidase in spinach chloroplasts. Plant Cell Physiol. 1981, 22, 867-880.

86. Rebouças, E.D.L.; Costa, J.J.N.; Passos, M.J.; Passos, J.R.S.; Hurk, R.; Silva, J.R.V. Real time PCR and importance of housekeepings genes for normalization and quantification of mRNA expression in different tissues. Braz. Arch. Biol. Technol. 2013, 56, 143-154. [CrossRef]

87. Livak, K.J.; Schmittgen, T.D. Analysis of relative gene expression data using real-time quantitative PCR and the 2-DDCT Method. Methods 2001, 25, 402-408. [CrossRef] [PubMed]

88. Medeiros, F.C.L.; Resende, M.L.V.; Medeiros, F.H.V.; Zhang, H.M.; Pare, P.W. Defense gene expression induced by a coffee-leaf extract formulation in tomato. Physiol. Mol. Plant Pathol. 2009, 74, 175-183. [CrossRef]

89. Hafez, E.E.; Hashem, M.; Balbaa, M.M.; El-Saadani, M.A.; Ahmed, S.A. Induction of new defensin genes in tomato plants via pathogens-biocontrol agent interaction. J. Plant Pathol. Microbiol. 2013, 4, 167.

90. Chen, C.; Chen, H.; Zhang, Y.; Thomas, H.R.; Frank, M.H.; He, Y.; Xia, R. TBtools: An integrative toolkit developed for interactive analyses of big biological data. Mol. Plant 2020, 13, 1194-1202. [CrossRef] 